\title{
Exploration on Cultivating Talents with Innovative Spirit and Entrepreneurial Ability by "Three Districts" Jointly in Colleges and Universities under the Background of "Internet+"
}

\author{
Yunshan Liu \\ School of Education, Wuxi Institute of Commerce, Wuxi, Jiangsu Province, China
}

Keywords: "Internet+", "Three district", Colleges and universities, Talents with innovative spirit and entrepreneurial ability, Cultivation mechanism.

\begin{abstract}
Colleges and universities, as a leading demonstration base of innovation and entrepreneur ship in economic society, should continue to strengthen research and exploration on the talent joint training mechanism under the background of the "Internet +" in the aspect of cultivating talents with innovative spirit and entrepreneurial ability. Colleges and universities should fully rely on the strength and advantages of the campus district, the science and education district and high-tech industrial district, and constantly open up new mechanisms and modes of cultivating talents with innovative spirit and entrepreneurial ability under the background of "Internet+".
\end{abstract}

\section{Introduction}

"Internet + " is an important new trend of development of social form in the world today. Its essence is to make full use of the optimized combination and integration effect of Internet technology in the allocation of social resources, to integrate the latest achievements of the Internet in various fields of economic society, to improve the productivity and creativity of the society so that the more effective and wider new form of Internet economic development can come into being. More than a decade, many industries in China and abroad are deeply integrated with the "Internet +" field. Colleges and universities, as a leading demonstration base of innovation and entrepreneurship in economic society, should continue to strengthen research and exploration on the talent joint training mechanism under the background of the "Internet + " in the aspect of cultivating talents with innovative spirit and entrepreneurial ability. Colleges and universities should fully rely on the strength and advantages of the campus district, the science and education district and high-tech industrial district, constantly open up new mechanisms and modes of cultivating talents with innovative spirit and entrepreneurial ability under the background of "Internet +" and transport high-quality talents for the construction of innovative countries.

\section{The Connotation and Characteristics of "Internet + "}

The connotation of "+" in "Internet +" refers to cross-border integration. It means openness, revolution and remodeling. "In the Internet age, innovation can only be made if we dare to cross boundaries, development can only be made when we dare to merge."1 In the world today, to achieve the sustainable development of economic society, we must rely on innovation. One of the goals and results of the G20 Hangzhou summit that held in September last year is also innovation-driven. We should make full use of Internet thinking to achieve changes and self-revolution, and we should always attach great importance to innovation-driven.

One of the key characteristics of "Internet $+"$ is remodeling. In the age of Internet, the fate of the human community has had a major structural remodeling. The original economy, society, geography, culture, information and other structures are broken, the original power, the right to speak, the rules 
are changed. Therefore, the "Internet + " social governance mechanism appears one after another. It continues to affect different industries. The cultivation mechanism of talent training in colleges and universities is also affected by it.

"Internet+" is also open and comprehensive. In the process of promoting and realizing "Internet+", we should strive to resolve the unfavorable links that constrain innovation and continue to absorb favorable factors that are conducive to the realization of the value of innovation and entrepreneurship.

\section{Cultivate Goal Synergy, Construct a New Mode of Talent Training}

The so-called talent training mode refers to the training according to the requirements of what kind of people should be trained and how to do the training. It also refers to the knowledge structure, ability need, all aspects of quality requirements and the methods on how to achieve these requirements in accordance with the quality and objectives of talent training. under the background of "Internet+", the new mode of cultivating talents with innovative spirit and Entrepreneurial ability in colleges and universities is to "make full use of the time space of online and offline, reality and virtuality"2. In the process of innovation and entrepreneurship education in colleges and universities, we should try to set up a new mode of talent training cooperated by campus district, science and education district and high-tech industrial district with the help of series of convenience in colleges and universities such as the science and technology district's entrepreneurial plan, the pooling effect of higher talents and good facilities service, etc.

The cultivation of talents with innovative spirit and entrepreneurial ability is a systematic project. It contains the concept, content, methods and institutional mechanisms of talent training and so on. To establish scientific and rational mode of cultivation of talents with innovative spirit and entrepreneurial ability, colleges and universities should firmly grasp the unity of innovation culture, ability and entrepreneurial quality on the basis of updating the educational concepts and ideas. Colleges and universities need to arrange the improvement of ideological awareness and the cultivation of entrepreneurship skills into the process of teaching and learning. In accordance with the needs of improving entrepreneurial skills and quality education, the colleges and universities need to design training objectives and teaching content, increase the level of teachers, make the school and enterprise progressed together, complete the comprehensive education of university students' ability, quality and professional knowledge, and cultivate talents with innovative spirit and entrepreneurial ability.

\section{Cultivate Demand Synergy, Determine the Scientific Content of Talent Training}

The content of cultivating talents with innovative spirit and entrepreneurial ability is determined by combining the four aspects of the talents on the basis of making full use of the advantages of "Internet+".

The first is solid expertise education. The solid expertise education is the main standard of measuring the quality of talents. Colleges and universities must improve the teaching of college students' public basic courses, professional basic courses and specialized courses. Based on the teaching, colleges and universities should add comprehensive courses, practice courses and entrepreneurship courses. Meanwhile, colleges and universities should consciously focus on the teaching of new knowledge and new skills which is in urgent need of science and education district and other industries.

The second is the cultivation of strong innovative spirit and entrepreneurial consciousness. It is the essential requirement of teaching in colleges and universities. The spirit of innovation and entrepreneurship is "a mental model that requires people to be good at capturing and taking advantages of opportunities, start from scratch, work hard, dare to take risks and open up"3. It is a kind of mental state with self-confidence and pragmatism, independent innovation, and cooperation. It is also a kind of ideology with wealth creation, promoting economic and social progress and development. Higher education should guide students to dare to break the routine, pass beyond the 
reality, and constantly cultivate the innovative spirit and entrepreneurial awareness of college students.

The third is better improvement of the practice ability of innovation and entrepreneurship. Colleges and universities should continue to strengthen the practice teaching and education, and enhance the innovative entrepreneurial skills of college students. They should establish a variety of training practice bases in the university science and education district, including "Internet + " training practice base. They need to regularly allow students to enter the district for professional practice and entrepreneurial practice. They need to encourage college students to participate in various innovative entrepreneurship competition, exercising the operational ability.

The fourth is the formation of good team spirit and collaboration ability. In the process of innovation and entrepreneurship, excellent team awareness and sincere spirit of collaboration play a decisive role. In addition to the appropriate project and decisive decision-making, the collaboration of team members is also important. When carrying out teaching of innovation and entrepreneurship in colleges and universities, it is necessary to pay attention to cultivate students a good sense of teamwork and collaboration spirit which are conducive to the success of innovation and entrepreneurship, and the improvement of the psychological quality.

\section{Cultivate Method Synergy, Adopt the Correct Talent Training Mode}

Firstly, in view of the teaching reform of education, on the one hand, the colleges and universities should organize the practical experience of innovation and entrepreneurship, flexibly arrange internships for college students, encourage students to study in the factory and other bases, and improve the exchange and cooperation among schools, science and education districts and social enterprises. They should also provide students chances to work in the production line, strengthen interaction between classes, practice sites of professional knowledge and social practice base, in order to achieve the formation of the collaboration inside and outside the schools. On the other hand, colleges and universities should adjust the teacher-centered education model, and establish student-centered education. Teachers should use advanced teaching equipment and various teaching programs, especially resources and methods of "Internet+", increase the amount of teaching information of innovation and entrepreneurship so that students can learn consciously and independently, and create a relax and lively teaching environment.

Secondly, colleges and universities need to strengthen the construction of teaching teams. The influence of teachers on the academic development and personality development of college students is straightforward and incalculable. The teachers must also have a strong spirit of innovation and strong entrepreneurial ability. Colleges and universities should cultivate teachers with higher teaching abilities in order to create and cultivate talents with innovative spirit and entrepreneurial ability, which is the basic condition. Colleges and universities should cultivate teachers with sufficient number, high quality, reasonable structure and high levels based on the cooperation with high-tech industrial district and science and education district, and the usage of channels such as the introduction, employment, selection, temporary posts. The first is to set up an institute which is responsible for the teaching of innovation and entrepreneurship of college students. Teachers in the institute should be full-time and compete for the position. The second is to employ senior technical staff with high-level teaching ability as professors in the aspect of innovation and entrepreneurship teaching through the high-tech industrial district and science and education district. The third is to hire some experts, scholars, government officials, entrepreneurs of high levels from research institutions, government departments as part-time instructors. The fourth is to select innovation and entrepreneurship teachers from schools to study in innovative enterprises, to ensure the improvement of teachers' business quality and the ability.

Thirdly, colleges and universities need to create a strong atmosphere of innovation and entrepreneurship. The strong atmosphere of innovation and entrepreneurship in colleges and universities, science and education districts and social enterprises has an unconscious influence to the talents with innovative spirit and entrepreneurial ability. Therefore, colleges and universities should create a good atmosphere of innovation and entrepreneurship to make students form the habit of 
innovation and entrepreneurship independently. The first is to strengthen the humanities quality education, improve the overall quality of college students. Colleges and universities need to carry out the philosophy, aesthetics, art, sociology, science, traditional culture and other courses, improve college students' aesthetic taste, cultural tastes, humanities and other comprehensive quality. The second is to organize monthly activities, and experience the infinite charm of innovation and entrepreneurship through the forms of visiting, competition, discussion and observation. Colleges and universities need to strengthen the cooperation between science and education districts and high-tech industrial districts, hold some influential innovation and entrepreneurship competitions, science and technology culture forum and so on, cultivate the campus innovation and entrepreneurship atmosphere, guide students to participate in innovation and entrepreneurship activities, make students create good habits. The third is to strengthen the research of innovation and entrepreneurship theory and lead innovation and entrepreneurship practice with advanced theoretical thinking. College and university science and education districts are where high-level innovative entrepreneurial talents gather. This provides advantageous conditions for the scientific research cooperation, theoretical discussion and subject research. It can also provide intellectual support for innovation and entrepreneurship associations and studios. The fourth is to develop the demonstration effect of innovation and entrepreneurship, and promote the formation of students' innovative and entrepreneurial personalities. Colleges and universities should collect and excavate the successful cases, and conduct extensive publicity reports by using the media such as windows, boards, radio, campus network and books. It can also be a good example for college students to actively devote themselves to innovation and entrepreneurship through the forms such as tour exhibitions and lectures.

The last is to create practical teaching platforms of innovation and entrepreneurship. The teaching is a whole system. For the freshmen, the "three districts" provide various work-study programs, and volunteer service positions. For the sophomores, the "three districts" provide short-term practice teaching, professional production internship. For the juniors, the "three districts" provide internship jobs to help students gradually accumulate work experience and improve employment ability and entrepreneurial ability. For the elites with innovative spirit and entrepreneurial ability, there are business incubation bases where can provide specialized practice and equipments to help them become self-employed. regularly by the school, university science park, hi-tech industrial park of experts to review its into the garden project, for access to training, to set aside an entrepreneurial venture fund, configuration mentors tracking guidance. The experts of "three districts" will regularly review the projects, train the admitters, provide the venture risk fund, and configure the following guidance.

\section{Cultivate Management Synergy, Provide a Powerful Safeguard of Talent Training}

To provide a powerful safeguard of talent training, the "three districts" should establish and perfect its organization protection measures, capital protection measures and evaluation protection measures.

Organization protection measures: The "three districts" need to establish leading organizations for students' innovation and entrepreneurship and be responsible for the overall planning, policy formulation and service management of the innovation and entrepreneurship teaching for college students.

Capital protection measures: The smooth development of college students' innovation and entrepreneurship requires sufficient funds. The "three districts" must raise a fully sufficient special fund for the teaching reform, promotion activities, trainings, and project incubation support and other projects. In addition, the "three districts" should also strive for the government's special funds for mass entrepreneurship and innovation, as well as raise venture capital funds from the society, individuals and communities for college students' innovation and entrepreneurship activities.

Evaluation protection measures: scientifically and rationally evaluate tutors and students according to the goals and requirements of students' innovation and entrepreneurship teaching. The focus of evaluating tutor performance is teaching and research and the focus of evaluating student performance is the ability. Through examinations, the evaluation for students should not only be 
comprehensive, but also be able to encourage students to make progress, be positive and progressive, be strict to themselves in accordance with the standards of innovation and entrepreneurship talents. All of these should refer to the conditions of entrepreneurial knowledge, entrepreneurial ideas, the development of entrepreneurial quality in each stage.

\section{References}

[1]Liang Li. Exploration on the Cultivation of College Students' Innovation Ability under the Background of "Internet+" [J]. Science and Education, 2016 (2).

[2]Ying Zhang. Reflections on the Mode of Cultivating Innovative Talents in Colleges and Universities [J]. Heilongjiang Education, 2008 (3).

[3]Yunshan Liu. An Analysis of the Core Values of College Students' Entrepreneurship in Employment Education [J]. Theoretical Circle, 2010 (10). 